\title{
Rule-based Dispute Settlement Mechanism for ASEAN Economic Community: Does ASEAN Have It?*
}

\author{
Koesrianti \\ Faculty of Law, Airlangga University \\ Jln. Darmawangsa Dalam Selatan, Surabaya, East Java, 60286, Indonesia. \\ Tel./Fax: +62-31-5020454 E-mail: koesrianti@fh.unair.ac.id \\ Submitted: May 14, 2016; Reviewed: Jun 8, 2016; Accepted: Jun 27, 2016
}

\begin{abstract}
ASEAN Charter 2007 as 'constitution' of ASEAN aims to establish ASEAN Community $(A C)$ in 2015 that ASEAN constitutes as a rule-based organization. ASEAN Community consists of three pillars, namely, ASEAN Political Security Community (APSC), ASEAN Economic Community (AEC), and ASEAN Socio Cultural Community (ASCC). AEC will posses as the lead for the Communities. The objective of AEC is to form a single market and production base with some priority sectors. Accordingly, many economic regional organizations provide Dispute Settlement Mechanism (DSM) to resolve disputes that may arise among the member countries. The dispute mechanism aims to provide predictability and security in international trade by providing strict time-frames, and was designed to be mutually agreed by the disputing members, flexible and binding. ASEAN trade DSM is designed as a legalistic mechanism. This paper examines DSM in ASEAN, especially economic disputes in the context of international trade law. In doing so, this paper analyzes DSM provided in the ASEAN Charter by comparing to DSM in the WTO context.
\end{abstract}

Keywords: AEC; ASEAN; Dispute Settlement Mechanism; Trade Dispute

DOI: http://dx.doi.org/10.20956/halrev.v1n2.303

\section{INTRODUCTION}

The ASEAN Charter establishes the group as an international legal entity. ${ }^{1}$ ASEAN exists in order to "maintain and enhance peace, security and stability and further strengthen peace-oriented values in the region". ${ }^{2}$ It is also said that ASEAN is a community, not just a group of nations thrown together by

Article 3 of ASEAN Charter, see at http://www.asean. org/archive/publications/ASEAN-Charter.pdf

2 Article 1 (1) of ASEAN Charter, Ibid. geographical proximity. ${ }^{3}$ In short, ASEAN is an intergovernmental organization that has international legal personality. ${ }^{4}$ ASEAN Member Countries (AMCs) have intended to establish ASEAN Community 2015 (AC15) which consist of three pillars namely ASEAN

3 Walter Woon. "The ASEAN Charter Dispute Settlement Mechanism". Available online at: http://www. worldscibooks.com/socialsci/6978.html

4 Koesrianti. (2013). International Legal Personality of ASEAN According to ASEAN Charter. Book Chapter, Purna Bakti Prof. Dr. Etty Agus, S.H., LL.M, University of Padjajaran. Bandung: Rosda Karya, p. 345.

${ }^{*}$ Revised article that had been presented in the $6^{\text {th }}$ CILS International Law Conference on Regional Integration, 5-6 October 2015, the Faculty of Law, Airlangga University, Surabaya-Indonesia. 
Political Security Community (APSC), ${ }^{5}$ ASEAN Economic Community (AEC), ${ }^{6}$ and ASEAN Socio-Cultural Community (ASCC). ${ }^{7}$

Among three pillars, the AEC can be said as the meat of the agreements. It has four characteristics namely, a single market and production base, a highly competitive economic region, a region of equitable economic development and a region fully integrated into the global economy. ASEAN region will be no trade barriers, tariff and non-tariff barriers economic region. Members adopted a blueprint of AEC to achieve a highly competitive economic region, with free-flowing goods, services, investment and skilled labor and capital. In other words, ASEAN economic integration has stressed the need for 'open regionalism' more than other regional economic groupings and indeed, the share of ASEAN's trade and investment interaction is extra-regional. ${ }^{8}$ This is an expression of ASEAN's development strategy. ${ }^{9}$

5 The APSC aims is to ensure the countries in the region live at peace with one another and with the world in a just, democratic and harmonious environment, for the APSC, http://www.asean.org/communities/aseanpolitical-security-community

6 The AEC is envisioned to be the realization of ASEAN economic integration by 2015. The regional economic integration process covers many wide-ranging of economic areas of cooperation among AMCs from initial focus on trade liberalization and now covers broader issues from investment to labor migration to Intellectual Property Rights (IPR). For the AEC, see http://www.asean.org/communities/asean-economiccommunity

7 The ASCC aims to contribute in realising AC15 that is people-oriented and socially responsible community to achieve enduring solidarity and unity in ASEAN region by adopting a common identity and build a caring and sharing society where the well-being, livelihood, and welfare of the peoples are enhanced. For the ASCC, see: http://www.asean.org/communities/asean-sociocultural-community

8 Siow Yue Chia and Michael G. Plummer. (2015). ASEAN Economic Cooperation and Integration: Progress, Challeges and Future Directions. Cambridge: Cambridge University Press, p 157.

$9 \quad$ Ibid.
The AEC is significantly important for AMCs as it is the realisation of the end goal of economic integration as espoused in the ASEAN Vision 2020. In the early economic agreements ASEAN first focus was on first pilar dealing with trade and investment liberalization. This vision is in fact to keep pace with the economic global phenomenon which involve liberalization in trade, investment and finance, with a minimum of legal or administrative obstruction. ${ }^{10}$ Eventually, ASEAN has moved to established a highly competitive economic region. In short, ASEAN intend to turn the diversity of the region into opportunities for business complementation and making the region a more dynamic and stronger segment of the global supply chain. It certainly will have disputes concerning implementation of ASEAN goals.

There are several challenge facing ASEAN in achieving its goals. Among other things, ASEAN has lack of a monitoring mechanism to ensure effective implementation, identification of priorities of ASEAN agreements, for each period and implementing bodies, and improve the coordination among the pillars, as well as resource mobilization. ${ }^{11}$ While progress has been made in lowering tariffs and some behind-the-border economic hurdles, nontariff barriers remain as major impediments to achieving a single market by 2025 . The liberalization of trade in services has also

10 Laurence Boulle. (2009). The Law of Globalization. USA: Wolters Kluwer, $\mathrm{p} 6$.

11 S. Pushpanathan. (2012). ASEAN's Readiness in Achieving the AEC 2015: Prospects and Challenges, in Ahieving the ASEAN Economic Community 2015: Challenges for Member Countries and Business. Singapore: ISEAS, p 15 
been slow despite the industry's growing importance in the region. All of these problems would become root of dispute among AMCs in achieving AEC goal. ASEAN, indeed, has provided dispute settlement mechanism in ASEAN Charter. Under ASEAN Charter, trade disputes shall be settled according to the ASEAN Protocol on Enhanced Dispute Settlement Mechanism of 2004 (hereinafter the Vientiane Protocol).

This article examines the trade dispute settlement mechanism in ASEAN especially the Vientiane Protocol whether it can adequately address trade disputes in the region with regard its sensitive and responsive to the ASEAN context. In doing so, this article will compare ASEAN DSM by refering to WTO DSM. ASEAN's trade dispute mechanism provided in the Vientiane Protocol, indeed, is very similar with the WTO dispute settlement mechanism. This article also observe on the meaning of trade disputes in the ASEAN context by comparing this with WTO DSM. Lastly it draws conclusion and suggestion.

\section{ANALYSIS AND DISCUSSION Brief Overview of AEC and the ASEAN Way}

The plan to establish AEC was originated from ASEAN Vision 202012 which was adopted in 1997 on the 30th anniversary of ASEAN. The ASEAN Vision 2020 clearly stated:

"[...] we commit ourselves to moving towards closer cohesion and economic integration, narrowing the gap in the level of development among

12 For ASEAN Vision 2020, see at http://www.asean.org/ news/item/asean-vision-2020
Member Countries, ensuring that the multilateral trading system remains fair and open, and achieving global competitiveness. [...] we will create a stable, prosperous, and highly cometitive ASEAN Economic Region in which there is a free flow of goods, services and investments, a freer flow of capital, equitable economic development and reduced poverty and socioeconomic disparities." 13

Thus, ASEAN main focus is to integrate the region become a single market and production base with free flow of goods, services, investments, capital and skilled labor by $2020 .{ }^{14}$ Later, in 2003, in the $9^{\text {th }}$ ASEAN Summit, the leaders signed the Declaration of ASEAN Concord II and agreed to establish the AEC by 2020 . The 2007 Cebu Declaration accelerated the establishment of the AEC to 2015, and ASEAN introduced the AEC Blueprint, which was substantiated into the Roadmap for the ASEAN Community (2009-2015), to guide the implementation of the AEC.

AsOctober 2013,279 measures(79,7\%) of the ASEAN Economic Community Blueprint have been implemented. ${ }^{15}$ This achievementwas based on the AEC Scorecard, ASEAN's self-assessment mechanism. The Scorecards further reveal that the pace of reform seems to have slowed, and need more synergy and disciplines from all of AMCs in implementing their commitment over the ASEAN economic agreements. It also partly because the process has reached the more

13 Ibid.

14 Nay Pyi Taw Declaration, 24th ASEAN Summit, 11 May 2014. See: http://www.asean.org/images/ documents/24thASEANSummit/Nay\%20Pyi $\% 20$ Taw\%20Declaration.pdf (Accessed 24/09/2015)

15 Chairman's Statement of the 23 ${ }^{\text {rd }}$ ASEAN Summit, Bandar Seri Begawan, Brunei Darussalam, 9 October 2013. 
difficult parts of the reform agenda. The $16^{\text {th }}$ ASEAN Summit in Vietnam has called for the speeding up of the implementation of ASEAN Agreements through timely ratification of agreements and protocols, as well as concrete actions. This however did not have a significant effect on AMS domestic levels. While progress has been made in lowering tariffs and some behind-the-border economic hurdles, non-tariff barriers remain as major impediments to achieving a single market by 2015 . The liberalization of trade in services has also been slow despite the industry's growing importance in the region. All of these problems should be resolved by utilizing legally binding approach rather than informal approach based on commitments only. ${ }^{16}$

The AEC aims is to establish ASEAN region as a single market and production base. It will create the region more dynamic and competitive region with new mechanism and measures to strengthen the implementation of its existing economic initiatives such as AFTA, ASEAN Framework Agreement on Services (AFAS) and ASEAN Investment Agreement (AIA). ASEAN also accelerate regional economic integration by priority sectors, namely, air travel, agro-based products, automotives, e-commerce, electronics, fisheries, healthcare, rubber-based products, textiles and apparels, tourism, and woodbased products.

In addition, ASEAN facilitating movement of business persons, skilled labour and talents. With over 600 million people,

16 Koesrianti. (2013). "The Establishment of AEC 2015: Economic Integration based on Commitments Without Sanction", Law Review, University of Pelita Harapan, 13(2): 325-327.
ASEAN's potential market is larger than the European Union or North America. Next to the People's Republic of China and India, ASEAN has the world's third largest labor force that remains relatively young. ${ }^{17}$ ASEAN thus shows the process of bringing regional cooperation to a higher plane, namely from economic cooperation towards greater economic integration. It can be said that so far ASEAN is the only fairly successful regional cooperation and integration organization in the third world, and perhaps second only to the European Union (EU) in this regard. Still, ASEAN needs more effort to realizing its goal, namely a single market and production base for the welfare of its people in globalized era, in particular in transforming regional interest to national action by surrendering national 's economic sovereignty to ASEAN economic policies. ${ }^{18}$

A single ASEAN market could, in principle, provide an alternative to investors both as host-location for foreign direct investment and a market for goods and services. Meanwhile production base means ASEAN intends to change the region become basis of products that can be marketed over the world. In other words, ASEAN enhance ASEAN's capacity to serve a global production center. ASEAN would be a part of the global supply chain. ASEAN focus on twelve sectors as priority products to accelerate ASEAN economic integration. Having say that, ASEAN should create a business

17 ASEAN Integration and the Private Sector, speech by ADB Vice-President Stephen Groff, 23 June 2014 in Berlin, Federal Republic of Germany, see http:// www.adb.org/news/speeches/keynote-speech-aseanintegration-and-private-sector-stephen-p-groff

18 Koesrianti. (2013). "International Cooperation Among States in Globalized Era: The Decline of State Sovereignty". Indonesia Law Review, 3(3): 267-284. 
environment suitable for foreign investors. It is necessary for ASEAN to have investment scheme and associated provisions, such as fair and equitable treatment of foreign investors to ensure the investment expectations. ${ }^{19}$ It can be said that business environment of certain country could have an impact to firm performance. In turn, firm performance can bring prosperous in the countries where the firm located. This is relevan as if ASEAN were one economy, it would be seventh largest in the world with a combined gross domestic product (GDP) of $\$ 2.4$ trillion in $2013 .^{20}$ It could be fourth largest by 2050 if growth trends continue.

The establishment of ASEAN Community (AC) is lead by economic integration. In other words, the AEC has a significant role for ASEAN as the AEC aims to create Southeast Asia region to be a competitive and equitable economic region. In order to fulfill economic integration of ten ASEAN members that have gap on economic development ${ }^{21}$ so that conflicting national economic interests among ASEAN members that caused disagreements are inevitable.

19 For the discussion of investment rules and their adjudications, see: David Scheneiderman. (2008). Constitutionalizing Economic Globalization: Investment Rules and Democracy's Promise. Cambridge: Cambridge University Press, pp 25-45.

20 ASEAN Integration and the Private Sector, speech by ADB Vice-President Stephen Groff, 23 June 2014 in Berlin, Federal Republic of Germany, see at http:// www.adb.org/news/speeches/keynote-speech-aseanintegration-and-private-sector-stephen-p-groff

21 ASEAN leaders have approved the Initiative for ASEAN Integration Strategic Framework and Work Plan (2009-15), which is meant to bridge the perceived "development divide" between the older and economically more advanced members - Brunei, Indonesia, Malaysia, Philippines, Singapore and Thailand, known as the ASEAN-6, and the four newer ones - Cambodia (1999), Lao People's Democratic Republic (1997), Myanmar (1997), and Viet Nam (1995), ADB publication: the ASEAN Economic Community: A Work in Progress, see, http://www.adb.org/publications/asean-economiccommunity-work-progress
In this context, reliable dispute settlement mechanism is vital for ASEAN. Through this mechanism, ASEAN can give legal certainty to producers and exporters that have business in the region. This certainty could be offered merely by creating a rule-based organization and an effective dispute settlement mechanism.

ASEAN at the beginning and until recently utilizes the ASEAN way as a mean to solve any differences or disagreement that may raise when one interact with another ASEAN members. ASEAN had utilized the ASEAN way as a mechanism of dispute settlement including trade disputes. The ASEAN way is "a norm of relations-based behavior" 22

There are three essential aspect of the ASEAN way: firstly, a desire not to lose face in public or to make other members lose face. Secondly, a preference for consensus rather than confrontation. Thirdly, a rejection of the notion that states have the right to interfere without consent in the internal affaris of other states. ASEAN, indeed, had performed its organizational operandi at informal basis.

ASEAN later did realize that it would be unrealistic to pretend that all disagreements can be resolved through diplomacy channels such as dialogue, consultation and negotiation. It can be said that this diplomacy mechanism does not support the thesis that these are invariably effective. ASEAN then intended to move to legalistic mechanism by adopting a charter.

\footnotetext{
22 Lee Leviter. (2010). The ASEAN Charter: ASEAN Failure or Member Failure. USA: New York University of International Law and Politics, Vol 43, p 159
} 
After a long discussion, the leaders issued the Declaration on the Establishment of the ASEAN Charter at the 11th ASEAN Summit held in Kuala Lumpur (December 2005). The declaration of the Charter aims was to create the legal and institutional framework for ASEAN, which had hitherto been functioning on a rather informal basis. Within two year the ASEAN leaders has adopted ASEAN Charter at the 13th ASEAN Summit in Singapore in November 2007. It came into force on 15 December 2008. By adopting the ASEAN Charter, ASEAN is now a ruled-base organization.

This is the remark of ASEAN, as the Charter can be regarded as the constitution of ASEAN. It can be said, however that ASEAN's main problem was not lack of vision. The main problem was following up on the grand declarations, plans of action and roadmaps. ${ }^{23}$ ASEAN, thus, must establish a culture of honouring and implementing its decisions and agreements, and carrying them out on time. The ASEAN Charter to aim for deeper integration in the future by implementing legal normative diciplines into ASEAN operational basis.

\section{Trade DSM in the ASEAN Context}

An inevitable feature of increased and deep of ASEAN economic cooperation and arrangement on trade is the emergence of disputes over the interpretation and implementation of the agreed upon commitments. Accordingly, reliable mechanisms for the settlement of trade related disputes have become necessary to ensure the effective and continued functioning of these arrange-

23 Report of the Eminent Persons Group on the ASEAN Charter, para 44. ments. In the multilateral context, the WTO dispute settlement mechanism is the best example that ASEAN can imitate. WTO dispute settlement mechanism has evolved from the relatively simple, diplomacy based structures called for in the GATT, to the detailed, legalistic, adjudication based mechanism found in the WTO. The main aim of the dispute settlement mechanism of the WTO is to secure a positive solution to a dispute. ${ }^{24}$ ASEAN dispute settlement mechanisms, however, adopts in varying degrees, legalistic adjudicatory processes in order to fulfil to the need to develop effective and workable dispute settlement mechanism.

The heart of $\mathrm{AC}$ is economic integration or AEC. Of three pillars, the AEC is the most advanced. The creation of an ASEAN Economic Community cannot take place without the existence of some means of settling disagreements amongst the AMCs over interpretation and implementation of the various economic agreements. Under the ASEAN Charter, the Vientiane Protocol is the main ASEAN rules and procedures for trade disputes.

The Vientiane Protocol is administered by the Senior Economic Officials Meeting (SEOM). It applies to disputes arising under the 1992 Framework Agreement on Enhancing ASEAN Economic Cooperation or other economic agreements set out in Appendix I to the Protocol, as well as future ASEAN economic agreements (referred to as "covered agreements"). The Charter extended

\footnotetext{
$24 \quad$ Surya P. Subedi. (2010). The WTO Dispute Settlement Mechanism as a New Technique for Settling Disputes in International Law, in International Law and Dispute Settlement: New Problems and Techniques. Duncan French, Matthew Saul and Nigel D. White (Eds.), Hart Publishing, p 175
} 
the coverage of the Vientiane Protocol to all ASEAN economic agreements. ASEAN Covered Agreements, initially 46 economic agreements and later on 79 economic agreements as covered agreement.

This Protocol is a mandatory dispute settlement system that consist of stages, namely, panels and appellate body to review disputes that cannot resolve through good offices, mediation or conciliation. This legalistic DSM is to support ASEAN as rulebased organization. Article 25 ASEAN Charter stated: "Appropriate dispute settlement mechanisms, including arbitration, shall be established for disputes which concern the interpretation or application of this Charter and other ASEAN instruments". Dispute settlement through arbitration is provided in Articles 10-17 and annex 4 of the DSM Protocol 2010. Arbitration based on consensus of the ASEAN Coordinating Council (ACC), which consist all of foreign ministers of AMCs. The arbitration provision in the ASEAN Charter is a compromise between AMCs that prefer diplomacy method and AMCs that pro legalistic dispute settlement mechanism.

Based on "the findings" of panel or appellate body, the AMCs that 'losing' the case shall amend their rule by issuing policies that conformed with ASEAN economic agreements. SEOM is authorized the "aggrieved party" to suspend concessions or other obligations under the covered agreements. The "offending state" is obliged to comply with its obligations under the covered agreements. Meanwhile, the Secretary General of ASEAN ex-officio can give good offices, conciliation or mediation
(Art 4 Protocol ESDM) to the parties in disputes. The Secretary has "a potentially significant role" in resolution of such disputes. The Vientiane Protocol is similar with the WTO DSU in the context that both mechanisms consist of Consultations, Panel, Appellate Body, and Compensation. The AMCs Foreign Ministers have adopted the Protocol to the ASEAN Charter on Dispute Settlement Mechanisms (Protocol 2010) ${ }^{25}$ on 8 April 2010 in Hanoi. This Protocol aims to fill the gaps when Treaty of Amity (TAC) or the Vientiane Protocol cannot be implemented.

\section{Trade Disputes in ASEAN}

Provision of Dispute Settlement Mechanism under ASEAN Charter

Article 22 ASEAN Charter stated that 'ASEAN shall maintain and establish dispute settlement mechanisms in all fields of ASEAN cooperation'. Furthermore, article 24 stated that where specific ASEAN instruments contain dispute settlement mechanisms so that disputes within the purview of the instrument should be settled in the manner stipulated. However, for trade disputes, article 24 (3) ASEAN Charter stated:

"...where not otherwise specifically provided, dispute which concern the interpretation or application of ASEAN economic agreements shall be settled in accordance with the Vientiane Protocol. ${ }^{26}$

\footnotetext{
25 The 2010 Protocol to the ASEAN Charter on Dispute Settlement Mechanisms adopted in Hanoi, Vietnam, on 8 April 2010, see at http://cil.nus.edu.sg/rp/pdf/2010\%20 Protocol $\% 20$ to $\% 20$ the $\% 20$ ASEAN\%20Charter $\% 20$ on $\% 20$ Dispute $\% 20$ Settlement $\% 20$ Mechanisms-pdf. pdf

26 The ASEAN Charter, Loc.Cit
} 
This article is the most important provision in the Charter, as the $\mathrm{AC}$ will depend mostly on economic integration. It is important to note that in order to have firm economic integration, ASEAN shall have binding dispute settlement mechanism in place to ensure that trade flows smoothly. Hence the Vientiane Protocol was a mean to ensure that legally-binding decisions could be made and expeditiously enforced, and this is a vital prerequisite for the AEC.

The main point of the Vientiane Protocol is the provision for the establishment of a panel to look into and objectively assess the dispute, make findings and recommendation on how it would be best resolved. ${ }^{27}$ This mechanism consists of consultation, panel process, appeal review process and adoption of appellate review report. The mechanism of this Protocol is very similar to the DSU of the WTO. Unlike non-economic cases, for the case of economic agreements, ASEAN provide a formal, comprehensive method for resolving disputes. It is interesting to note, however, that the Vientiane Protocol never utilized by ASEAN Member Countries.

Unlike the ASEAN DSM, there is provision on trade dispute in the WTO DSM. The DSM of the WTO is a central element in providing security and predictability to the multilateral trading system. In the WTO DSM context, the main rules and procedure of the DSM is the Understanding on Rules and Procedures Governing the Settlement of Disputes (hereinafter the DSU). ${ }^{28}$ The

\footnotetext{
27 Koesrianti. (2005). The Development of the ASEAN Trade Dispute Settlement Mechanism: From Diplomacy to Legalism, UNSW Sydney, pp. 256 - 271, (Unpublished Dissertation) for detailed of the DSM processes.

28 The DSU WTO, see at https://www.wto.org/english/ tratop_e/dispu_e/dsu_e.htm
}

Members recognize that the mechanism serves to preserve the rights and obligations of Members under the covered agreements. The Covered Agreement of WTO provided for in Appendix 1 of the DSU and it consists of 83 (eighty three) distinct matters. ${ }^{29}$

\section{What is trade dispute in the ASEAN context?}

GATT 1947 best describes trade dispute, which entitled as nullification or impairment (Article XXIII GATT 1947). Article XXIII GATT stated: ${ }^{30}$

(1) If any contracting party should consider that any benefit accruing to it directly or indirectly under this Agreement is being nullified or impaired or that the attainment of any objective of the Agreement is being impeded as the result of:

a. The failure of another contracting party to carry out its obligations under the Agreement, or

b. The application by another contracting party of any measure, whether or not it conflict with the provisions of this Agreement, or

c. The existence of any other situation, the contracting party may, with a view to the satisfactory adjustment of the matter, make written representations or proposals to the other contracting party or parties which it consider to be concerned. Any contracting party thus approached shall give sympathetic consideration to the representations or proposals made to it.

(2) If no satisfactory adjustment is effected between the contracting parties

29 The WTO Covered Agreements, see at https://www. wto.org/english/res_e/booksp_e/analytic_index e/ dsu_09_e.htm\#app_1

30 Article XXIII GATT 1947, see at https://www.wto.org/ english/docs_e/legal_e/gatt47_02_e.htm\#articleXXII 
concerned within a reasonable time, or if the difficulty is of the type described in paragraph 1 (c) of this Article, the matter may be referred to the CONTRACTING PARTIES. The CONTRACTING PARTIES shall promptly investigate any matter so referred to them and shall make appropriate recommendations to the contracting parties which they consider to be concerned, or give a ruling on the matter, as appropriate. The CONTRACTING PARTIES may consult with contracting parties, with the Economic and Social Council of the United Nations and with any appropriate inter-governmental organization in cases where they consider such consultation necessary. If the CONTRACTING PARTIES consider that the circumstances are serious enough to justify such action, they may authorize a contracting party or parties to suspend the application to any other contracting party or parties of such concessions or other obligations under this Agreement as they determine to be appropriate in the circumstances...

In essence, a dispute arises when one country adopts a trade policy measure or takes some action that one or more fellowWTO members considers to be breaking the WTO agreements, or to be a failure to live up to obligations. Disputes in the WTO are essentially about broken promises. WTO members have agreed that if they believe fellow-members are violating trade rules, they will use the multilateral system of settling disputes instead of taking action unilaterally.

In the ASEAN DSM context, there is no provision on nullification and impairment as provide in Article XXIII GATT 1947. This GATT 1947 provision on trade dispute had been modified as emerging dispute set- tlement procedures. This dispute settlement system gradually evolved, from a power based system through diplomatic negotiations into a system that had many of features of a rules-based system of dispute settlement through adjudication. ${ }^{31}$

Ernst-Ulrich Petersmann wrote with respect to the evolution of GATT dispute settlement: The economic, political, and legal advantages of this progressive "judicialization" of GATT dispute settlement procedures are obvious. For example:

1. Rules, and their "rule-oriented" rather than "power-oriented" interpretation and application, enhance predictability and legal security, limit the risks of abuse of power, reduce transaction costs of traders and procedures, increase the scope for decentralized decision-making and thereby promote liberty and economic welfare. It is an everyday experience that traders, investors and consumers prefer to do business where rules are observed and enforced.

2. Legal dispute settlement and enforcement mechanisms render international treaties more effective and credible and are essential to maintain confidence in the GATT system;

3. Panel reports, dispute settlement rulings, arbitration awards an court decisions, generally build up consistent case law and evolve into time tested precedents, generally accepted interpretations and new rules which may fill "gaps" in existing treaty law an

31 Peter Van den Bossche. (2005). The Law and Policy of the World Trade Organization: Text, Cases and Materials. UK: Cambridge, p 178 
progressively transform multilateral treaties into more consistent legal systems. ${ }^{32}$

In the ASEAN context, however, there is no such thing about nullification or impairment or definition trade dispute, as well as, the fact that from the date of adoption of the Vientiane Protocol up until now there is no single case being brought to ASEAN DSM. This zero case in the ASEAN DSM becomes big question. Does really no case on trade among the AMCs.? Or there are other problems. Since one or two ASEAN Member Countries have been a complainant, respondent or third parties in WTO DSM. For example, Indonesia has been complainant in 10 cases, as respondent in 13 cases and as third party in 13 cases. ${ }^{33}$ Not only Indonesia against WTO Members nonASEAN Members, in 1 June 2015 Viet Nam files dispute against Indonesia regarding Indonesia's imposition of a safeguards measures on imports of flat-rolled products of iron or non-alloy steel. ${ }^{34}$

The WTO case that involve ASEAN Member Countries including a case that the parties are Thailand and Philippines on cigarette. On 7 February 2008, the Philippines requested consultations with Thailand concerning a number of Thai fiscal and customs measures affecting cigarettes from the Philippines. Such measures include Thailand's customs valuation practices, excise

32 E.U. Petersmann (1998), The GATT/WTO Dispute Settlement System: International Law, International Organizations and Dispute Settlement, Kluwer Law International, p 85-86 quoted in Peter Van den Bosch, Loc.Cit.

33 Dispute by country/territory https://www.wto.org/ english/tratop_e/dispu_e/dispu_by_country_e.htm

34 Viet Nam against Indonesia in WTO DSM see https://www.wto.org/english/news_e/news15_e/ ds496rfc_01jun15_e.htm tax, health tax, TV tax, VAT regime, retail licensing requirements and import guarantees imposed upon cigarette importers. The Philippines claims that Thailand administers these measures in a partial and unreasonable manner and thereby violates Article X:3(a) of the GATT 1994. This case has been upheld and Thailand has violated WTO agreement. Dispute DS371, 2008: The panel report recommending that Thailand bring the offending measures into conformity with its obligations was adopted on 15 July 2011). ${ }^{35}$ Other ASEAN Member Countries, Singapore as complainant, respondent, and third party in the WTO DSM are 1, 0 and 20 cases respectively. Philippine as complainant 5 cases, respondent 6 cases and third party 14 cases. This data shows that the AMCs do have involved in trade dispute in WTO DSM and even have trade disputes among them. Thus, the AMCs unfortunately, prefer to bring their disputes to the WTO DSM instead of the ASEAN DSM.

It seems difficult for AMCs to bring their disputes to ASEAN DSM as when they do so, especially from ASEAN Foreign Ministers point of view, a binding dispute settlement mechanism is a serious step. Since this mechanism will reduce full sovereignty of their government. The choice however is between a tested mechanism and an untested one. This is a policy dilemma for the AMCs government. Hence if none of ASEAN member countries tries to use the ASEAN DSM provided in Vientiane Protocol, then this mechanism will never be tested. If

\footnotetext{
35 The summary of Appellate Body Report was up-to-date at 26 June 2014, see at https://www.wto.org/english/ tratop_e/dispu_e/cases_e/1pagesum_e/ds371sum_e. pdf (viewed 20/08/2015)
} 
the AMCs have ever try this mechanism out for their disputes, and then something goes wrong, it needs some corrections and reviews for the better of ASEAN future. If the establishment of AEC is more than a political solidarity, the AMCs should bring their trade disputes to ASEAN DSM thereby ASEAN show its commitment towards the AEC goals. The AEC 2015 should be viewed not as the final destination but as a milestone of the long journey towards the AEC.

\section{CONCLUSION}

ASEAN has moved from economic cooperation to economic integration, from merely association to community. ASEAN is not a group of nations but it is a community with some legal consequences and really need commitment from AMCs. The locomotive of the ASEAN Community is the AEC. The AEC aims to establish a single market and production base, create a highly competitive region, narrowing gap between the AMCs, and connecting with the global economy.

In order to achieve the AEC's goals, ASEAN have to implement of its existing economic initiatives such as AFTA, ASEAN Framework Agreement on Services (AFAS) and AIA. ASEAN also accelerate regional economic integration by priority sectors, namely, air travel, agro-based products, automotives, e-commerce, electronics, fisheries, healthcare, rubber-based products, textiles and apparels, tourism, and wood-based products. ASEAN had utilized the ASEAN way as a mechanism of dispute settlement including trade disputes. The ASEAN way is a norm of relations-based behavior. However, it would be unwise to have a dispute settlement mechanism based entirely on consensual mechanisms.

Year 2015, the year of establishment of AEC, should be viewed as a momentum for AMCs to get the AEC goal came true. In this process, economic agreement disputes may arise. ASEAN has the ASEAN DSM in place, but until recently the ASEAN DSM never utilize by the AMCs to solve their disputes. The AMCs have brought their case to the WTO DSM instead of the ASEAN DSM. Frankly speaking, it also would be unwise for the AMCs that bring their disputes to multilateral level. For the regional problems should be solved by regional mechanism. The Vientiane Protocol needs to be tested by the AMCs should there were problems than ASEAN can fix it, so that the Protocol becomes a tested mechanism instead of an untested mechanism forever.

\section{BIBLIOGRAPHY}

David Scheneiderman. (2008). Constitutionalizing Economic Globalization: Investment Rules and Democracy's Promise. UK: Cambridge University Press.

Ernest Ulrich Petersmann (1998), The GATT/WTO Dispute Settlement System: International Law, International Organizations and Dispute Settlement. USA: Kluwer Law International.

Koesrianti. (2005). The Development of the ASEAN Trade Dispute Settlement Mechanism: From Diplomacy to Legalism, UNSW Sydney, pp. 256 - 271, (Unpublished Dissertation) for detailed of the DSM processes.

Koesrianti. (2013). "International Coopera- 
tion Among States in Globalized Era: The Decline of State Sovereignty". Indonesia Law Review, 3(3): 267-284.

Koesrianti. (2013). "The Establishment of AEC 2015: Economic Integration based on Commitments Without Sanction", Law Review, University of Pelita Harapan, 13(2): 325-327.

Koesrianti. (2013). International Legal Personality of ASEAN According to ASEAN Charter. Book Chapter, Purna Bakti Prof. Dr. Etty Agus, S.H., LL.M, University of Padjajaran. Bandung: Rosda Karya.

Laurence Boulle. (2009). The Law of Globalization. USA: Wolters Kluwer.

Lee Leviter. (2010). The ASEAN Charter: ASEAN Failure or Member Failure. USA: New York University of International Law and Politics, Vol 43.

Peter Van den Bossche. (2005). The Law and Policy of the World Trade Organization: Text, Cases and Materials. UK: Cambridge.

S. Pushpanathan. (2012). ASEAN's Readiness in Achieving the AEC 2015: Prospects and Challenges, in Ahieving the ASEAN Economic Community 2015: Challenges for Member Countries and Business. Singapore: ISEAS.

Siow Yue Chia and Michael G. Plummer. (2015). ASEAN Economic Cooperation and Integration: Progress, Challeges and Future Directions. UK: Cambridge University Press.

Surya P. Subedi. (2010). The WTO Dispute Settlement Mechanism as a New Technique for Settling Disputes in International Law, in International Law and
Dispute Settlement: New Problems and Techniques. Duncan French, Matthew Saul and Nigel D. White (Eds.), Hart Publishing.

Walter Woon. "The ASEAN Charter Dispute Settlement Mechanism". Available online at: http://www.worldscibooks. com/socialsci/6978.html

\section{Website:}

ADB publication: the ASEAN Economic Community: A Work in Progress, see, http://www.adb.org/publications/asean-economic-community-work-prog$\underline{\text { ress }}$

Article XXIII GATT 1947, https://www. wto.org/english/docs_e/legal_e/ gatt47 02 e.htm\#articleXXII

ASEAN Charter, see at http://www.asean. org/archive/publications/ASEANCharter.pdf

ASEAN Integration and the Private Sector, speech by ADB Vice-President Stephen Groff, 23 June 2014 in Berlin, Federal Republic of Germany, see http://www.adb.org/news/speeches/ keynote-speech-asean-integrationand-private-sector-stephen-p-groff

ASEAN Vision 2020, see at http://www.asean.org/news/item/asean-vision-2020

Chairman's Statement of the $23^{\text {rd }}$ ASEAN Summit, Bandar Seri Begawan, Brunei Darussalam, 9 October 2013.

Dispute by country/territory https://www. wto.org/english/tratop e/dispu e/dispu by country e.htm

Nay Pyi Taw Declaration, 24th ASEAN Summit, 11 May 2014., see at: http://www.asean.org/images/docu 
ments/24thASEANSummit/Nay $\% 20$

Pyi\%20Taw\%20Declaration.pdf

Report of the Eminent Persons Group on the

ASEAN Charter, http://www.asean. org/asean/asean-charter/eminent-persons-group-epg-on-the-asean-char$\underline{\text { ter-2006 }}$

The 2010 Protocol to the ASEAN Charter on Dispute Settlement Mechanisms adopted in Hanoi, Vietnam, on 8 April 2010, http://cil.nus.edu.sg/ rp/pdf $/ 2010 \% 20$ Protocol $\% 20$ to $\% 20$ the $\% 20$ ASEAN $\% 20$ Charter $\% 20$ on $\% 20$ Dispute $\% 20$ Settlement $\% 20$ Mechanisms-pdf.pdf

The AEC, see http://www.asean.org/commu nities/asean-economic-community

The APSC, http://www.asean.org/commu $\underline{\text { nities/asean-political-security-commu }}$ nity

The ASCC, see http://www.asean.org/communities/asean-socio-cultural-community

The DSU WTO, https://www.wto.org/english/tratop e/dispu e/dsu e.htm

The summary of Appellate Body Report was up-to-date at 26 June 2014, see at https://www.wto.org/english/tratop e/ dispu_e/cases_e/1pagesum_e/ ds371sum e.pdf

The WTO Covered Agreement, https://www. wto.org/english/res e/booksp e/analytic index e/dsu 09 e.htm\#app 1

Viet Nam against Indonesia in WTO DSM see https://www.wto.org/english/news_e/ news15 e/ds496rfc 01jun15 e.htm 